\title{
Global Climate Change and Biodiversity: Issues and Future Research
}

\section{Dafeng Hui*}

Department of Biological Sciences, Tennessee State University, Nashville, TN 37209, USA

\section{Editorial}

Biological diversity, commonly referred to as biodiversity, is a measure of variation of life forms within a given species, ecosystem, biome, or planet [1-3]. Biodiversity includes diversity within species (genetic diversity), between species (species diversity) and of ecosystems [4]. Biodiversity plays an important role in maintaining ecosystem productivity, stability, sustainability and other ecosystem services that are essential for human well-being [5-8]. Loss of biodiversity has become a serious issue in many places around the world. Many factors, such as habit loss and degradation, excessive nutrient load, air and water pollution, over-exploitation and unsustainable use of natural resources, and invasive species, contribute to the loss of biodiversity $[6,8]$. However, global climate change is often considered as one of the major factors causing biodiversity loss $[6,7,9]$.

Global climate change is occurring at an unprecedented rate today mainly due to an increased emission of greenhouse gases such as atmospheric $\mathrm{CO}_{2}$ [10]. Global temperatures have increased by about $0.6-0.76^{\circ} \mathrm{C}$ since the mid- $1800 \mathrm{~s}$ and are predicted to further increase by $1.4^{\circ} \mathrm{C}$ to $5.8^{\circ} \mathrm{C}$ by 2100 [10]. Global mean sea level has risen by 12 to $22 \mathrm{~cm}$ during the last century. During the next century, precipitation is also anticipated to increase by about $0.5-1 \%$ per decade for most middle- and high-latitude land areas in the northern hemisphere, causing more frequent flooding and droughts [10-12]. Since climate is the fundamental factor that determines organism life-stages such as plant germination and flowering, it can severely alter habitats and food sources for animals, and ultimately, could have significant impacts on biodiversity of species and ecosystems around the world.

Global Climate Change affects our physical and biological environments, thus, it influences biodiversity both directly and indirectly through its interaction with other environmental factors [8,13]. Living organisms and ecosystems need to adapt to climate change through shifting habitats, changing life cycles, or developing new physical traits [7,8,11,14-16]. Documented effects of climate change on biodiversity and ecosystems mainly include: 1) species extinction and biodiversity loss. Climate change has led to a sharp increase in the rate of species extinction [6,11,13,17]. The Millennium Ecosystem Assessment (2005) highlighted a substantial loss of biodiversity on Earth, with some 10$30 \%$ of mammal, bird and amphibian species threatened with extinction [18]. 2) Phenology changes. Changes in phenology (i.e. time of natural events such as reproduction in certain species or the length of growing season) have been documented in many species including both plants and animals $[11,13,16,19]$. For example, higher temperatures have led to earlier flowering in certain plant species [20] and an increase in the number of eggs laid by the spruce budworm [21]. 3) Shifts in geographic range. Climate change forces organisms to respond by adapting or migrating, and results in geographic range changes for species $[6,8]$. As an example, the northern boundaries moved further north for some plants and animals as temperature increased [14]. 4) Ecosystem functioning and service changes. Ecosystem production and stability are closely linked to biodiversity. Loss of biodiversity due to climate and land use change may lead to increased greenhouse gas emissions, further exacerbating climate change $[5,8]$. In contrast, increases in biodiversity could enhance ecosystem productivity and carbon sequestration, and may reduce the negative effects of climate change.

Substantial advances have been made in the past decades in our understanding of climate change effects on biodiversity. However, we still face many research challenges today [6-8]. More research is needed to improve our understanding of the effects of climate change on biodiversity and ecosystem functioning, particularly in the following three aspects: 1) To accurately describe the biodiversity change/trend and facilitate the comparison among different ecosystems and at different temporal scales, adequate biodiversity indicators and advanced analytic methods should be developed [22,23]. As changes in temperature and precipitation differ among different places, the effects of climate change on biodiversity may vary spatially and temporally. Since policy makers and resource managers are more interested in biodiversity at regional or national scales, these indicators should be able to scale up from a local to a regional and finally, a global scale [22]. A measure of the uncertainty in the estimates and ecological modeling should also be defined [23-25]. 2) To better understand climate change effects on biodiversity, observational networks ranging from local to international levels should continue to reinforce data collection on the range shifts of species and changes in ecosystem status [6,25-27]. Efforts should also be made to develop vulnerability assessments, identify flagship or keystone species, and evaluate the distribution and impacts of invasive species under climate change. Meta-data including climatic factors, land use change, fire etc should be recorded so both the direct and indirect effects of climate change on biodiversity could be investigated. 3) To predict the future impacts of climate change on biodiversity, integrating measured data with ecological models is an important and common approach [9,28-30]. At least two types of models have been widely used to simulate species distribution changes: bioclimatic envelope models and the more advanced dynamic or process-based models [31-33]. Since the dynamic models typically take factors such as lifehistory traits of species and processes such as dispersal and migration into account, they may provide better forecasts of species distribution changes under climate change. But most modeling studies on species distribution changes are only based on isothermal shifts and focused on a selected number of species [13]. Thus, improving data quality and reducing model uncertainty are also very important $[6,23]$.

Overall, climate change has significantly changed biodiversity and will further increase species and ecosystem biodiversity loss. Due to the complexity of the problem at both spatial and temporal scales, it is a

*Corresponding author: Dafeng Hui, Department of Biological Sciences, Tennessee State University, Nashville, TN 37209, USA, Tel: +1 615963 5777; Fax: 1615963 5783; E-mail: dhui@Tnstate.edu

Received June 25, 2013; Accepted June 28, 2013; Published July 03, 2013

Citation: Hui D (2013) Global Climate Change and Biodiversity: Issues and Future Research. J Biodivers Endanger Species 1: e105. doi:10.4172/jbes.1000e105

Copyright: (c) 2013 Hui D. This is an open-access article distributed under the terms of the Creative Commons Attribution License, which permits unrestricted use, distribution, and reproduction in any medium, provided the original author and source are credited. 
Citation: Hui D (2013) Global Climate Change and Biodiversity: Issues and Future Research. J Biodivers Endanger Species 1: e105. doi:10.4172/ jbes.1000e105

difficult task to accurately and reliably estimate and predict the impacts of climate change on biodiversity [6,8]. Further research on critical issues may improve our understanding of the effects of climate change and mitigate its influence on biodiversity $[6-8,29,30]$.

\section{References}

1. Wilcox BA (1984) In situ conservation of genetic resources: determinants of minimum area requirements. Proceedings of the World Congress on National Parks, Smithsonian Institution Press, USA

2. Harper JL, Hawksworth DL (1994) Biodiversity: measurement and estimation. Springer 345: 5-12.

3. Gaston KJ, Spice JI (2004) Biodiversity: an introduction. 2ndedn, Blackwel Publishing, UK.

4. Heywood VH, Watson RT (1995) Global Biodiversity Assessment. UNEP Cambridge University Press, Cambridge, UK.

5. Mooney HA, Cushman JH, Medina E, Sala OE, Schulze E-D (1996) Functiona Roles of Biodiversity: A Global Perspective. ICSU-UNEP. JohnWiley, Chichester, UK.

6. Kappelle M, Van Vuuren MMI, Baas P (1999) Effects of climate change on biodiversity: a review and identification of key research issues. Biodiversity and Conservation 8: 1383-1397.

7. Pereira HM, Navarro LM, Martins IS (2012) Global Biodiversity Change: The Bad, the Good, and the Unknown. Annual Review of Environment and Resources 37: 25-50.

8. Vittoz P, Cherix D, Gonseth Y, Lubino V, Maggini R, et al (2013) Climate change impacts on biodiversity in Switzerland: A review. Journal for Nature Conservation 21: 154-162.

9. Dawson TP, Jackson ST, House JI, Prentice IC, Mace GM (2011) Beyond Predictions: Biodiversity Conservation in a Changing Climate. Science 332: 53-58.

10. Intergovernmental Panel on Climate Change (2007) Climate Change 2007 The Physical Science Basis. Cambridge University Press, Cambridge, UK

11. McNeely JA, Gadgil M, Leveque C, Padoch C, Redford K (1995) Human influences on biodiversity. Global Biodiversity Assessment, Cambridge University Press, UNEP, Cambridge, UK.

12. Hui D, Tian H, Luo Y (2012) Impacts of Climatic Changes on Biogeochemical Cycling in Terrestrial Ecosystems. Handbook of Climate Change Mitigation, Springer.

13. Ogawa-Onishi Y, Berry PM (2013) Ecological impacts of climate change in Japan: The importance of integrating local and international publications. Biological Conservation 157: 361-371.

14. Parmesan C, Yohe G (2003) A globally coherent fingerprint of climate change impacts across natural systems. Nature 421: 37-42.

15. Bellard C, Bretelsmeier C, Leadley P, Thuiller W, courchamp F (2012) Impacts of climate change on the future of biodiversity. Ecology Letters 15: 365-377.

16. Mantyka-Pringle CS, Martin TG, Rhodes JR (2012) Interactions between

Citation: Hui D (2013) Global Climate Change and Biodiversity: Issues and Future Research. J Biodivers Endanger Species 1: e105. doi:10.4172 jbes.1000e105 climate and habitat loss effects on biodiversity: a systematic review and metaanalysis. Global Change Biology 18: 1239-1252.

17. Kannan R, James DA (2009) Effects of climate change on global biodiversity: a review of key literature. Tropical Ecology 50: 31-39.

18. Millennium Ecosystem Assessment (2005) Ecosystems and Human WellBeing: Biodiversity Synthesis. World Resource Institute, Washington, DC, US.

19. Root TL, Price JT, Hall KR, Schneider SH, Rosenzweig C, et al (2003) Fingerprints of global warming on wild animals and plants. Nature 421: 57-60.

20. Sherry RA, Luo Y, Zhou X, Gu S, Arnone III JA et al (2007) Divergence of reproductive phenology under climate warming. Proceedings of National Academy of Sciences of United States of America 104:198-202

21. Gitay H, Suárez A, Watson RT, Dokken DJ (2002) Climate Change and Biodiversity. Intergovernmental Panel on Climate Change, Geneva, Swizerland.

22. Scholes RJ, Biggs R (2005) A biodiversity intactness index. Nature 434: 45-49.

23. Dornelas M, Magurran AE, Buckland ST, Chao A, Chazdon RL, et al (2013) Quantifying temporal change in biodiversity: challenges and opportunities. Proceedings of the Royal Society B-Biological Sciences 280: 20121931.

24. Hui DF, Biggs O, Scholes RJ, Jackson RB (2008) Measuring uncertainty in estimates of biodiversity loss: The example of biodiversity intactness variance. Biological Conservation 141: 1091-1094.

25. Tubiello FN, Soussana JF, Howden SM (2007) Crop and pasture response to climate change. Proceedings of the National Academy of Sciences of the United States of America 104: 19686-19690.

26. Robertson MP, Cumming GS, Erasmus BFN (2010) Getting the most out of atlas data. Diversity and Distributions 16: 363-375.

27. Scholes RJ, Mace GM, Turner W, Geller GN, Jurgens N, et al (2008) Toward global biodiversity observing system. Science 321: 1044-1045.

28. Rocchini D, Hortal J, Lengyel S, Lobo JM, Jimênez-Valverde, et al (2011) Accounting for uncertainty when mapping species distributions: The need fo maps of ignorance. Progress in Physical Geography 35: 211-226.

29. Lavergne S, Mouquet N, Thuiller W, Ronce O (2010) Biodiversity and Climate Change: Integrating Evolutionary and Ecological Responses of Species and Communities. Annual Review of Ecology, Evolution and Systematics 41: 321 350

30. Thuiller W, Albert C, Araújo MB, Berry PM, Cabeza M, et al (2008) Predicting global change impacts on plant species' distributions: Future challenges. Perspectives in Plant Ecology Evolution and Systematics 9: 137-152.

31. Mokany K, Ferrier S (2011) Predicting impacts of climate change on biodiversity: a role for semi-mechanistic community-level modelling. Diversity and Distributions 17: 374-380.

32. Ibanez I, Clark JS, Dietze MC, Feeley K, Hersh M, et al (2006) Predicting biodiversity change: Outside the climate envelope, beyond the species-area curve. Ecology 87: 1896-1906.

33. Rowland EL, Davison JE, Graumlich LJ (2011) Approaches to evaluating climate change impacts on species: a guide to initiating the adaptation planning process. Environmental Management 47: 322-337.

Submit your next manuscript and get advantages of OMICS Group submissions

Unique features:

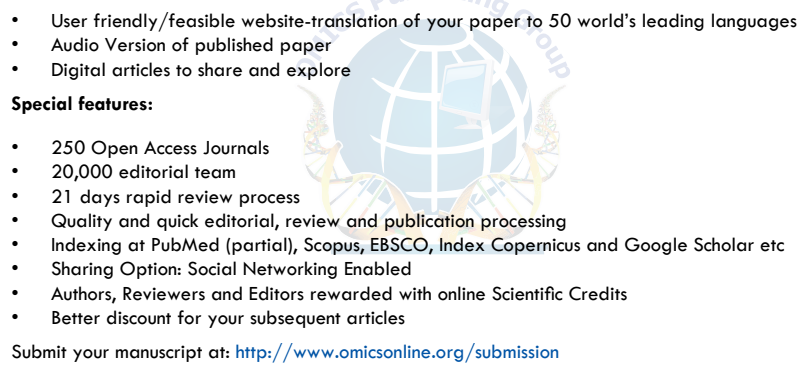

